\title{
The Usage of Red Mud and Black Nickel Mud for Removal of Methylene Blue
}

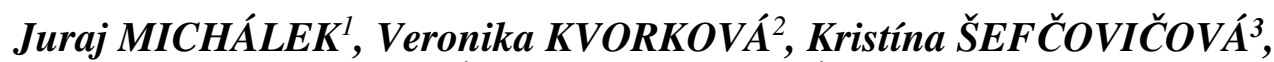 \\ Alexandra KUCMANOVÁ4 and Maroš SOLDÁN ${ }^{5 *}$
}

\begin{abstract}
Authors' affiliations and addresses:
${ }^{1}$ Slovak University of Technology, Faculty of

Materials Science and Technology in Trnava, J.

Bottu 2781/25, 91724 Trnava, Slovakia

e-mail: juraj.michalek@stuba.sk

${ }^{2}$ Slovak University of Technology, Faculty of Materials Science and Technology in Trnava, J. Bottu 2781/25, 91724 Trnava, Slovakia

e-mail: veronika.kvorkova@stuba.sk

${ }^{3}$ Slovak University of Technology, Faculty of Materials Science and Technology in Trnava, J. Bottu 2781/25, 91724 Trnava, Slovakia e-mail: kristina.sefcovicova@stuba.sk

${ }^{4}$ Slovak University of Technology, Faculty of Materials Science and Technology in Trnava, J. Bottu 2781/25, 91724 Trnava, Slovakia e-mail: alexandra.kucmanova@stuba.sk

${ }^{5}$ Slovak University of Technology, Faculty of Materials Science and Technology in Trnava, J. Bottu 2781/25, 91724 Trnava, Slovakia e-mail: maros.soldan@stuba.sk
\end{abstract}

\section{*Correspondence:}

Maroš Soldán, Slovak University of Technology in Bratislava, Faculty of Materials Science and Technology in Trnava, J. Bottu, 2781/25, 91724 Trnava, Slovakia

tel: +421918646066

e-mail: maros.soldan@stuba.sk

\section{Acknowledgement:}

This work was supported by the Grant Agency KEGA of the Slovak Ministry of Education, Science, Research and Sport via project no. 013TUKE4/2019: "Modern educational tools and methods for forming creativity and increasing practical skills and habits for graduates of technical university study programmes ".

How to cite this article:

Michálek, J., Kvorková, V., Šefčovičová, K., Kucmanová, A. and.Soldán, M.(2021). The Usage of Red Mud and Black Nickel Mud for Removal of Methylene Blue. Acta Montanistica Slovaca, Volume 26 (3), 546-554

DOI:

https://doi.org/10.46544/AMS.v26i3.12

\begin{abstract}
Dyes are used as a coloured compound and are considered highly toxic to their adverse effects on many forms of life. Adsorption is the most comprehensively used technology due to simplicity, low cost, and effectiveness for removing dyes from water solution. This article discusses the use of adsorbents from waste metal production - red mud (RM) and black nickel mud (BNM) for methylene blue removal from water solution. RM was obtained from Žiar n. Hronom (Slovakia) - waste from aluminium oxide production from the abovementioned ash pond and BNM was supplied from the waste landfill in Sered' (Slovakia) - waste from nickel production. The adjusted samples were used as adsorbents in different test conditions, such as time and temperature of sorption and amount of sorbent samples. The experiment was done at the varied amount of sorbent $0.2,0.4$ and 0.6 $\mathrm{g}$ per $75 \mathrm{ml}$ of sorptive with a fraction of adsorbent particles < $500 \mu \mathrm{m}$. The solution of methylene blue was prepared with a concentration of $50 \mathrm{mg} / \mathrm{L}$. The sorption process was realised by various conditions. The temperature of sorption was $25^{\circ} \mathrm{C}, 40^{\circ} \mathrm{C}$ and $60{ }^{\circ} \mathrm{C}$ and the contact time of the sorbent with the sorptive was 1,2 , 3, 24 and 48 hours. From the obtained data, we can claim the best removal efficiency at $60^{\circ} \mathrm{C}$ for $\mathrm{RM}(83.01-83.72 \%$ after $48 \mathrm{~h}$ ) regardless of the amount added to the methylene blue solution. We can conclude that after appropriate treatment, both of these low-cost adsorbents can be an interesting alternative to remove methylene blue using sorption under the right conditions.
\end{abstract}

\section{Keywords}

Red mud, black nickel mud, sorption, methylene blue

(C) 2021 by the authors. Submitted for possible open access publication under the terms and conditions of the Creative Commons Attribution (CC BY) license (http://creativecommons.org/licenses/by/4.0/). 


\section{Introduction}

The various types of dyes are an important class of synthetic organic compounds used in many industries. Consequently, they have become common pollutants present in the environment. Colour is usually the first contaminant to be recognised in wastewater and affects the aesthetic merit, transparency and gas solubility of water bodies (Pereira and Alves, 2012). The sources of pollution include domestic agricultural and industrial water (Rajasulochana and Preethy, 2016). With the growing development of the textile industry, water pollution has also increased. It is estimated that more than $10^{3}$ tonnes of dyes are consumed annually in the textile industry per year, with around 100 tonnes/year going to watercourses (Yagub et al., 2014).

Methylene blue (methylthioninium chloride) (MB) is a cationic dye from the phenothiazines family, is a tricyclic phenothiazine, soluble in water and some organic solvents. This dye has various applications in chemistry, biology, medical science and dyeing industries. Long term exposure of MB can cause vomiting, nausea, anaemia and hypertension (Foo, 2012; Hameed, 2009).

The main methods of regeneration of dye-contaminated waters include biological treatment, ion-exchange, coagulation/flocculation, microelectrolysis, advanced oxidation processes, adsorption, membrane filtration, photocatalysis and various combinations of these methods. The advantages and disadvantages of every removal technique have been reviewed (Hameed, 2009; Salleh et al., 2011).

Removal of colour from dye-containing wastewater is a major concern, and the point of degrading dyes is not only to remove colour but to eliminate, or decrease, the toxicity (Pereira and Alves, 2012). Adsorption of different types of pollutants from solution is a superior choice with many advantages over the other processes, and it is considered to be one of the most appropriate and effective techniques for removing dyes from aqueous solutions due to its simplicity, high efficiency, and wide-ranging availability of adsorbent materials (Thakare et al., 2020; Kazak et al., 2017; Yin et al., 2015). Several research articles bring information concerning the adsorption capacity of different commercially available adsorbents for water in various ways (Ciahotný et al., 2016). Therefore, there is a tremendous demand for developing cheap and efficient methods for the removal of pollutants from water. Sorption methods are still considered promising in regard to the cost/efficiency factor, and new sorbents are being developed (Štefušová et al., 2012). A widespread application of adsorptive processes in environmental protection technologies depends first of all on the prices of adsorbents put on the market (Sobolewski, 1998).

It is well known that solid waste materials (by-products) generated from various industrial activities pose one of society's most vexing problems. The solid waste generated from industries used as adsorbents for water and wastewater treatment is an interesting and beneficial alternative. If it reduces the volume of solid waste, it can reduce pollution (Thakare et al., 2020).

RM is aluminium industry waste; it has received wide attention as an effective adsorbent for water pollution control, showing significant adsorption potential to remove various aquatic pollutants. Among various industrial by-products, RM is a solid waste residue formed after the caustic digestion of bauxite ores during alumina production. Each year, about 90 million tonnes of RM are produced globally (Bhatnagar et al., 2011; Kumar, S., Kumar, R. and Bandopadhya, 2011). RM typically contains various minerals such as aragonite, calcite, gibbsite, opal, and goethite. It usually contains various chemical components such as $\mathrm{CaO}, \mathrm{Fe}_{2} \mathrm{O}_{3}, \mathrm{Al}_{2} \mathrm{O}_{3}, \mathrm{SiO}_{2}, \mathrm{TiO}_{2}$, and $\mathrm{Na}_{2} \mathrm{O}$ (Belviso et al., 2018). Nevertheless, $\mathrm{RM}$ is a potentially inexpensive material for preparing adsorbents with its high specific surface area, fine particle size, and strong adsorption (Wang et al., 2020This industry waste is a high alkaline material and thus cannot be directly added into the water. So, before using red mud, it needs to be neutralised (Zhou and Haynes, 2010). In Slovakia, the aluminium oxide was produced mainly by sintering in the aluminium mill in Žiar n. Hronom from 1957 to 1997 (Kafka and Čambálová, 2001). Recently, several researchers found that red mud could be successfully used as the adsorbent for dye removal (de Souza et al., 2013; Ratnamala et al., 2012; Thakare et al., 2020; Zhong-Pan et al., 2017).

BNM was created by the leaching of nickel and cobalt from lateritic iron-ore. It contains chromium oxide, silicon, aluminium, calcium, and the rest of nickel is essentially iron concentrate. In Slovakia, nickel was produced from the Albanian iron-nickel ore with a nickel content of about $1 \%$. Annual production of BNM was about $3 \times$ $10^{5} \mathrm{~kg}$, and supplies in Slovakia are estimated at 5.6 million tons (Soldán et al., 2013).

The research studying the sorption of dyes using red mud or black nickel mud is very rare. Therefore, more research is needed in this area to understand the adsorption mechanism between dyes and these adsorbents.

In this work, the calcinated RM and NBM were taken as the adsorbents for MB removal. The aim of this study was to find out a low-cost adsorbent for wastewater treatment. The affecting factors including adsorbent dosage, contact time and temperature were studied. The efficiency of the removal process was calculated, and results are shown as $\mathrm{C} / \mathrm{C}_{0}$ versus time plots. 


\section{Materials}

\section{Materials and Methods}

Methylene blue was dissolved in distilled water to reach a concentration of solution $50 \mathrm{mg} . \mathrm{l}^{-1}$.<smiles>CN(C)c1ccc2nc3ccc(=[N+](C)C)cc-3sc2c1</smiles><smiles>[SiH3]</smiles>

Fig. 1. The chemical structure of $M B$

In the experiment, we have applied adsorption to remove methylene blue (MB) from the solution. Red mud (RM) and black nickel mud (BNM) were used as adsorbents. Both of them were stored in a laboratory under atmospheric conditions. This experiment focused on different test conditions, such as time and temperature of sorption and weight of sorbent samples.

RM used in the present experiments was supplied from Žiar n. Hronom - waste from metal production from the above-mentioned ash pond.

BNM in the present experiments was supplied from the waste landfill in Sered' - waste from metal production. BNM used in this study was obtained from the Albanic iron-nickel in Sered'. Since 1963 the Albanian iron-nickel ore has been processed in Niklová huta, š.p., Sered' and lies at $125 \mathrm{~m}$ a.s.l. on the southern edge of Dolnovážska niva on the intersection of the cadastral areas of Sered' and Dolná Streda (Michaeli et al., 2012).

Soldán and Kobetičová (2015) investigated the chemical composition (Tab. 1) and morphology (Fig. 2, 3) of adsorbents in this article using a scanning electron microscope and EDX analysis. In RM, they identified rutile $\left(\mathrm{TiO}_{2}\right)$, hematite $\left(\mathrm{Fe}_{2} \mathrm{O}_{3}\right)$, limestone $\left(\mathrm{CaCO}_{3}\right)$, halloysite $\left(\mathrm{Al}_{2} \mathrm{Si}_{2} \mathrm{O}_{5}(\mathrm{OH})_{4}\right)$ and bayerite $\left(\mathrm{Al}(\mathrm{OH})_{3}\right)$. BNM contained mainly hematite, schorlomite $\mathrm{Ca}_{3}(\mathrm{Fe}, \mathrm{Ti})_{2}\left[(\mathrm{Si}, \mathrm{Ti}) \mathrm{O}_{4}\right]_{3}$, calcite $\left(\mathrm{CaCO}_{3}\right)$, magnetite $\left(\mathrm{Fe}_{3} \mathrm{O}_{4}\right)$ and sillimanite $\left(\mathrm{Al}_{2} \mathrm{SiO}_{5}\right)$.

Tab. 1. Percentage of RM and BNM elements (Soldán and Kobetičová, 2015)

\begin{tabular}{|c|c|c|c|c|c|c|c|}
\hline Adsorbent & $\begin{array}{c}\mathrm{O} \\
{[\%]}\end{array}$ & $\begin{array}{c}\mathrm{Al} \\
{[\%]}\end{array}$ & $\begin{array}{c}\mathrm{Si} \\
{[\%]}\end{array}$ & $\begin{array}{l}\mathrm{Mg} \\
{[\%]}\end{array}$ & $\begin{array}{l}\mathrm{Ca} \\
{[\%]}\end{array}$ & $\begin{array}{c}\mathrm{Ti} \\
{[\%]}\end{array}$ & $\begin{array}{l}\mathrm{Fe} \\
{[\%]}\end{array}$ \\
\hline Red mud & 34.31 & 7.74 & 5.02 & - & 11.48 & 2.6 & 38.83 \\
\hline Black nickel mud & 25.31 & 4.97 & 4.56 & 3.48 & 3.70 & - & 67.29 \\
\hline
\end{tabular}

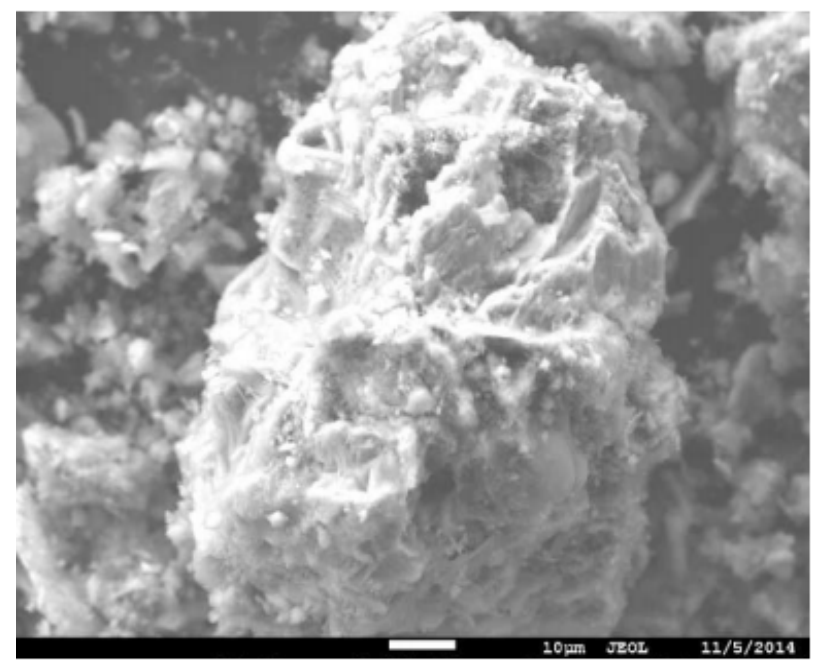

Fig. 2. Microscopic appearance of the sorbent surface of RM (Kobetičová et al., 2017) 


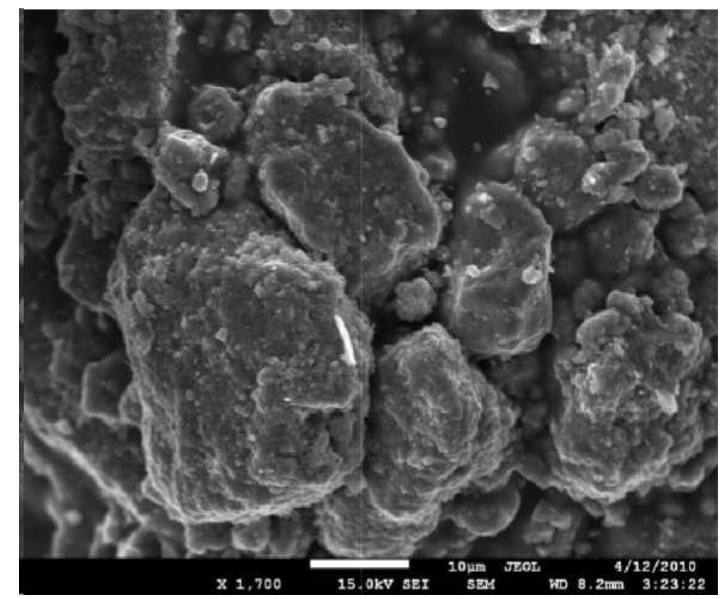

Fig. 3. Microscopic appearance of the sorbent surface of BNM (Soldán and Kobetičová, 2015)

\section{Pre-treatment of adsorbents}

Pre-treatment of the samples of RM and BNM was proposed to remove possible organic impurities that could have a negative effect on the sorption capacity of the sorbents. Sorbents were annealed in a muffle furnace, VEB ELECTRO Bad Frankenhausen LM 312.11 at $600{ }^{\circ} \mathrm{C}$ for four hours to remove possible organic impurities. After the annealing process, cooling in a desiccator was performed. The requested fraction of the RM particles $(<500$ $\mu \mathrm{m})$ were used for all characterisation and dye sorption study. As shown by Kobetičová et al. (2017), after annealing of the adsorbent (RM), there were changes in the peaks compared to the original unannealed samples, which may lead to changes in the sorption properties of the material. Therefore, FT-IR analysis of the samples was performed before and after annealing.

\section{Fourier Transform Infrared Spectroscopy}

FT-IR spectra of the samples were obtained using a Fourier Transform Infra-Red Spectrometer (FTIR) of Varian 660 MidIRDual MCT/DTGS Bundle. The ATR equipment for measuring solid particles of red mud was used. Spectra were measured 100 times at a resolution of $4 \mathrm{~cm}^{-1}$, with a filter of $1.28 \mathrm{kHz}$ and a rate of $5 \mathrm{kHz}$, recorded and evaluated by using software with the library VarianResolutionsPro Sadtler Canadian forensics.

\section{UV/Vis Spectrophotometry}

The absorbance of MB was determined by spectrophotometer GENESYS 8 in UV / VIS area (500-800 nm). The highest light absorbance (amount of light absorbed by the material) of MB is at $665 \mathrm{~nm}$. For the measurement, plastic cuvettes of $1 \mathrm{~cm}$ thick were used. The maximal absorbance (at $665 \mathrm{~nm}$ ) was used to calculate the efficiency of absorbents.

\section{Adsorption experiments}

MB solution $(75 \mathrm{ml})$ was taken to the Erlenmeyer flasks, and $0.2 \mathrm{~g}$ of RM and BNM were added. In the experimental part, the efficiency of the sorption with the sorbents and the influence of the sorption conditions were observed. The solution was homogenised by HEIDOLPH Promax 1020 shaker at a rate of $160 \mathrm{~T}^{\mathrm{min}}{ }^{-1}$. Tested samples were stirred throughout the whole time of sorption. Sorption depends on the contact time of the sorbent with the sorptive; each measurement was performed after 1, 2, 3, 24 and 48 hours. The amount of sorbent can affect the sorption efficiency. Therefore, the experiment was done at the varied amount of sorbent $0.2,0.4$ and 0.6 g per $75 \mathrm{ml}$ of sorptive. During investigating the effect of temperature (using the MEMMERT 100-800 dryer) on sorption, the shaker was not used, and the homogenisation of the solution was performed manually. The study of the effect of temperature change has used the temperature of $25^{\circ} \mathrm{C}, 40^{\circ} \mathrm{C}$ and $60^{\circ} \mathrm{C}$. Subsequently, the samples were placed in a JANETZKI T30 centrifuge for 10 minutes at the specified time. The rotational speed of 2000$3000 \mathrm{~g}$ to sediment the small, undesirable particles of sorbent. The procedures of the experiment are shown in Fig. 4. 


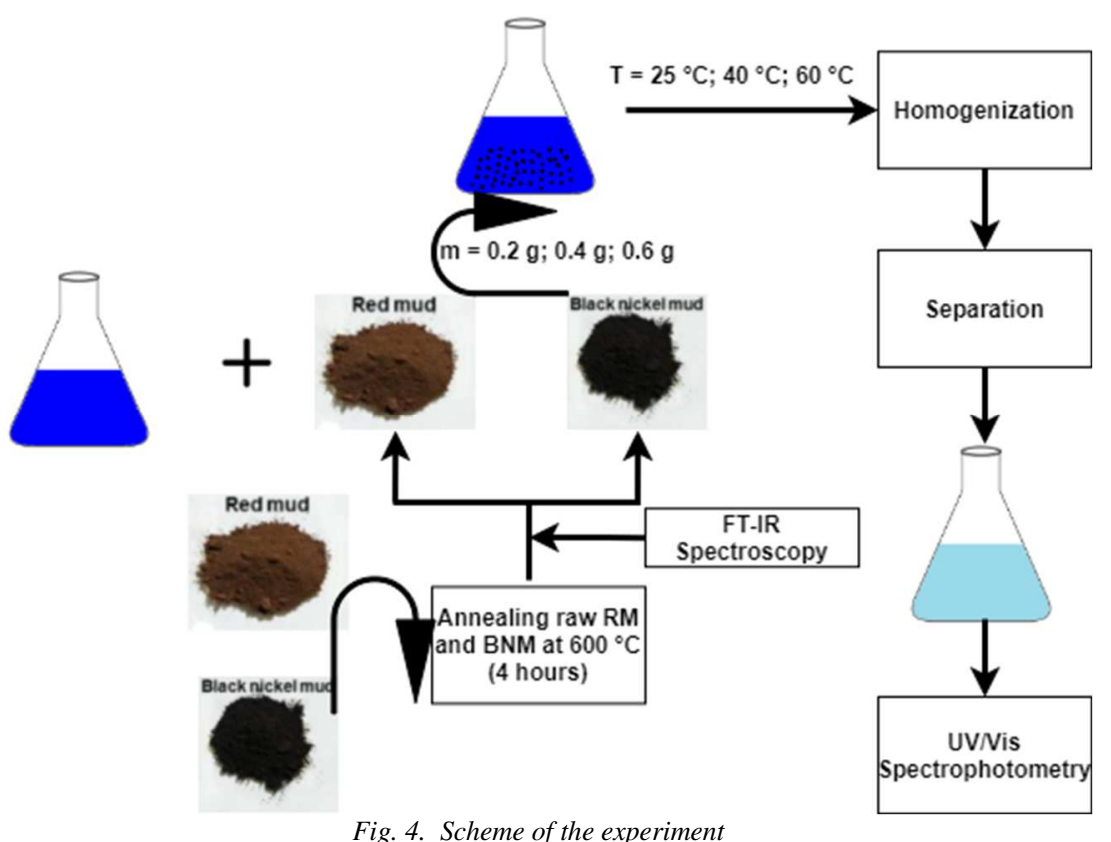

Results and Discussion

\section{FT-IR Analysis}

Fig. 5 shows FT-IR spectra of unannealed and annealed RM. The main absorption bands in unannealed RM were observed at $3444,2989,2902,2358,2341,1407,989,873,798,528$ and $433 \mathrm{~cm}^{-1}$, whereas in the spectra of annealed RM at $600{ }^{\circ} \mathrm{C}$ for four hours by peaks at $2364,2343,1400,985,869,709,536,455 \mathrm{~cm}^{-1}$ wavenumbers were observed. The band at $3444 \mathrm{~cm}^{-1}$ could be assigned to stretching bonds of surface water molecules or to an envelope formed by hydrogen surface $\mathrm{OH}$ groups (Gotić and Musić, 2007). Peaks at 2989 and $2902 \mathrm{~cm}^{-1}$ correspond to $\mathrm{CH}_{2}$ symmetric or asymmetric stretch (Christou et al., 2018); this can present organic hydrocarbon compound as an impurity in RM. Peaks at 1407 and $1400 \mathrm{~cm}^{-1}$ match the carbonate component, possibly from calcite (Al Bakri Abdullah et al., 2012). Individual peaks between the range $433-989 \mathrm{~cm}^{-1}$ could be identified as quartz and hematite phases (Dodoo-Arhin et al., 2013). The big difference can be visible between $2431-2364 \mathrm{~cm}^{-}$ ${ }^{1}$, which can possibly represent the water molecules associated with the ferrihydrite and another hydrate (Singh et al., 2019).

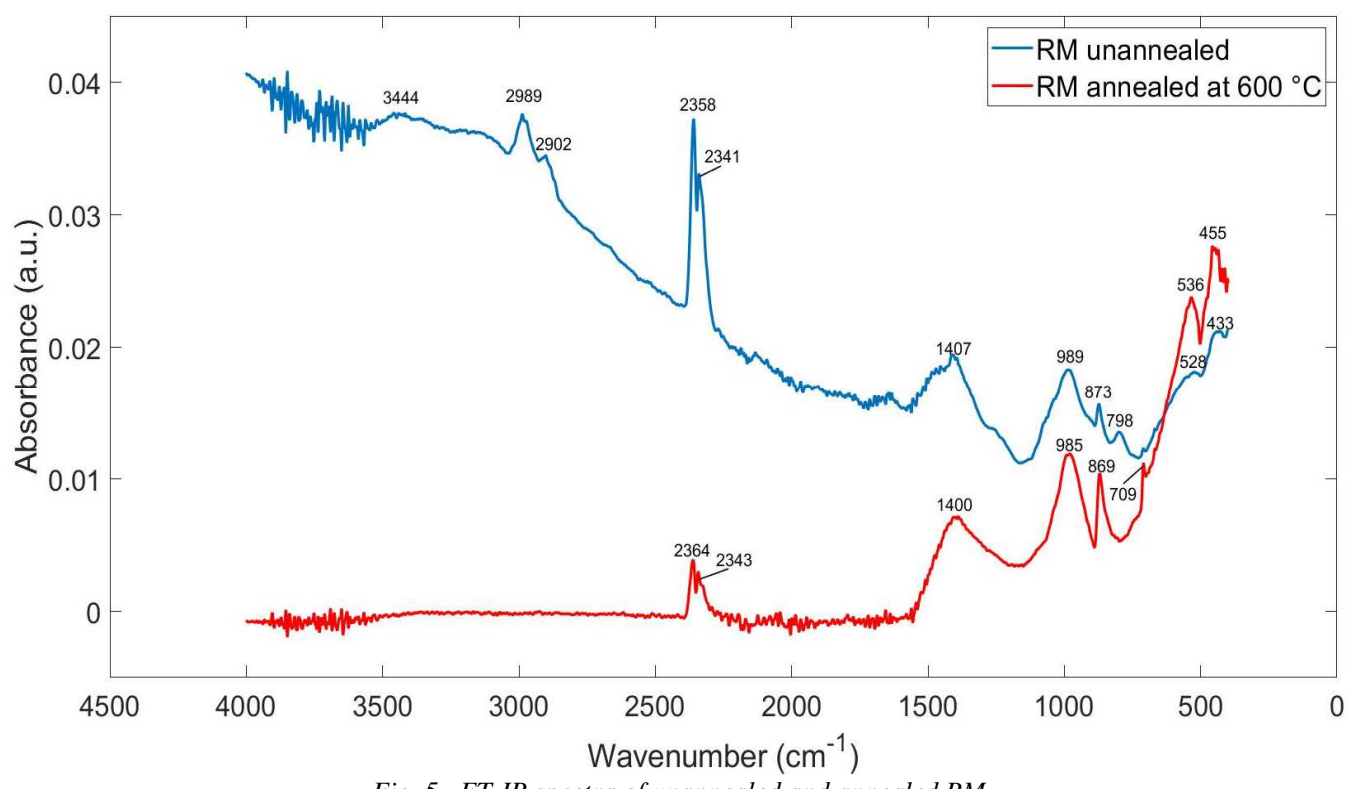

Fig. 5. FT-IR spectra of unannealed and annealed RM

The main absorptions bands shown in Fig. 6 for unannealed and annealed BNM at $600{ }^{\circ} \mathrm{C}$ for four hours are: $3205,2985,2917,2850,2364,2358,2341,2337,1482,1455,1388,993,968,873,856,794,555,553,447,400$ 
$\mathrm{cm}^{-1}$. The peak at $3205 \mathrm{~cm}^{-1}$ corresponds to $\mathrm{OH}$ groups (Gotić and Musić, 2007). Little peaks at 2985, 2917, 2850 $\mathrm{cm}^{-1}$ correspond to $\mathrm{CH}_{2}$ stretch. Bands at $1482,1455,1388 \mathrm{~cm}^{-1}$ are possibly from calcite (Al Bakri Abdullah et al., 2012). Individuals peaks between wavenumbers at $400-993 \mathrm{~cm}^{-1}$ could be quartz and hematite phases (DodooArhin et al., 2013). The sharp peak between wavenumbers $2337-2364 \mathrm{~cm}^{-1}$ could be attributed to the deformation vibration of H-O-H associated with weakly bonded water molecules (Cudennec and Lacerf, 2006).

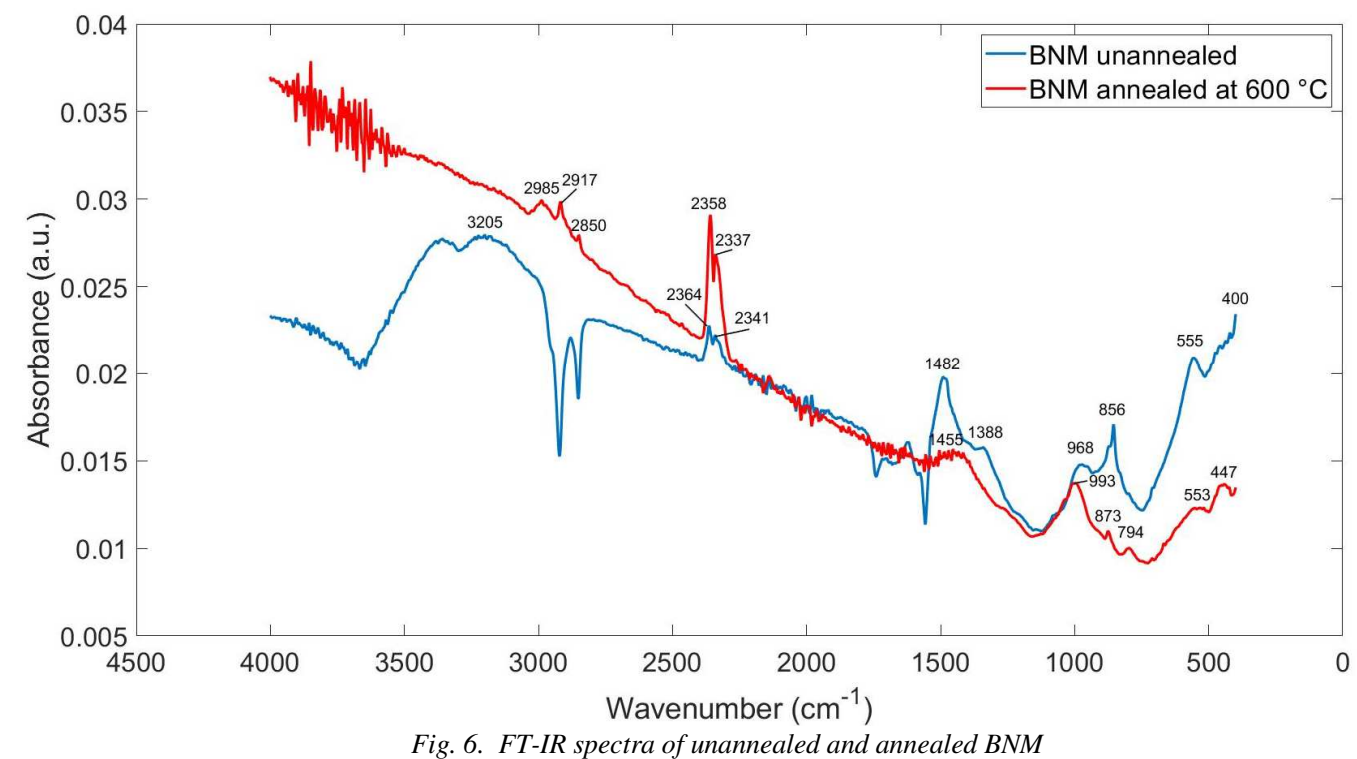

\section{Adsorption experiments results}

As shown in Fig. 7A), adsorption at $25^{\circ} \mathrm{C}$ is very ineffective even after $48 \mathrm{~h}$ (efficiency $2.45 \%$ for $0.2 \mathrm{~g}$, $3.66 \%$ for $0.4 \mathrm{~g}$ and $4.67 \%$ for $0.6 \mathrm{~g}$ of RM). It can be useful to look at efficiency after a long time of adsorption or with a bigger amount of RM. According to Fig. $7 \mathrm{~A}$ ) at $25^{\circ} \mathrm{C}$ for the amount of BNM $0.2 \mathrm{~g}$ and $0.4 \mathrm{~g}$ methylene blue concentration decrease very slowly (efficiency $1.64 \%$ and $4.52 \%$ after $48 \mathrm{~h}$ ), but $0.6 \mathrm{~g}$ pf BNM shows a significant decrease in the concentration of MB with increasing time of sorption (efficiency $34.62 \%$ after $48 \mathrm{~h}$ ), which put the question how would the efficiency looks like with the bigger amount of BNM and after longer time of adsorption.

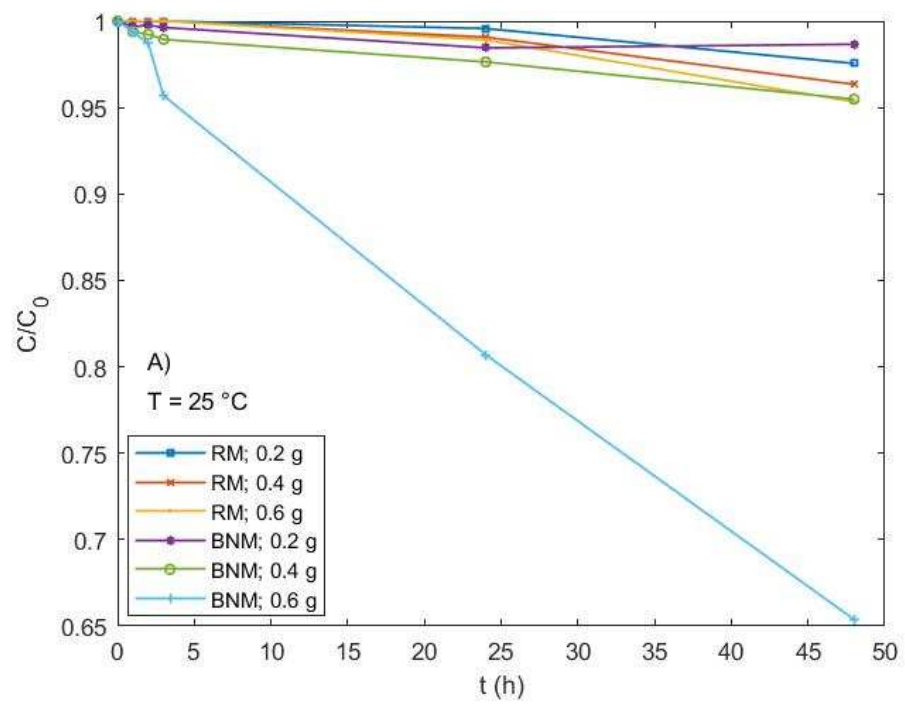

Fig. 7. A) $C / C_{0}$ vs t plot of methylene blue $\left(C_{0}=50 \mathrm{mg} / \mathrm{L}\right)$ adsorption with various dosages of RM and BNM at $25^{\circ} \mathrm{C}$

Looking at Fig. 7B) at $40{ }^{\circ} \mathrm{C}$, it makes no sense to use BNM compared to RM in all quantities examined. With $0.6 \mathrm{~g}$ of RM, we can see that after $24 \mathrm{~h}$ adsorption process is close to the equilibrium because efficiency up to $48 \mathrm{~h}$ rises only slightly from $48.47 \%$ to $55.38 \%$. Over all the temperature of $40^{\circ} \mathrm{C}$ is quite ineffective even after $48 \mathrm{~h}$. For RM, it would be interesting to try higher times, mainly with an amount of $0.2 \mathrm{~g}$, because efficiency increases three times after $48 \mathrm{~h}(34.01 \%)$ than after $24 \mathrm{~h}(10.90 \%)$. 


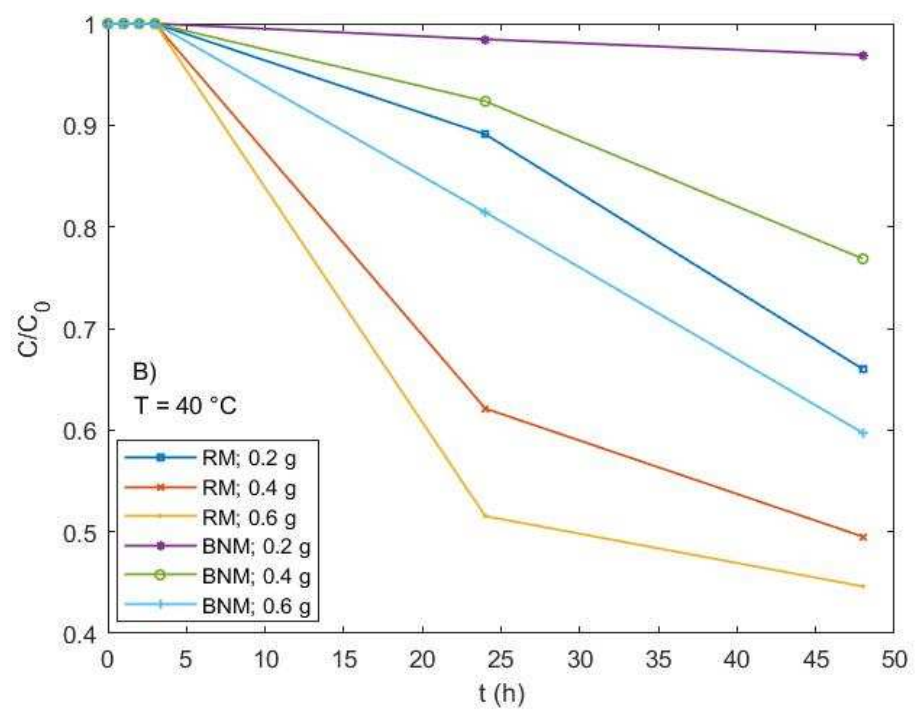

Fig. 7. B) $C / C_{0}$ vs t plot of methylene blue $\left(C_{0}=50 \mathrm{mg} / \mathrm{L}\right)$ adsorption with various dosages of $R M$ and $B N M$ at $40^{\circ} \mathrm{C}$

In conclusion, the best removal efficiency is at $60^{\circ} \mathrm{C}$ for $\mathrm{RM}(83.01-83.72 \%$ after $48 \mathrm{~h})$ regardless of the amount added to the solution of methylene blue because the amount of RM has a negligible effect on adsorption efficiency according to the Fig. 7C). Similar efficiency is achieved by BNM at this temperature with amounts of 0.4 and $0.6 \mathrm{~g} \mathrm{(78 \%}$ and $79.07 \%)$, but the needed contact time is $48 \mathrm{~h}$, whereas for RM $24 \mathrm{~h}$ is enough to the similar value of removal efficiency. That means the equilibrium with BNM is achieved after $48 \mathrm{~h}$, but with RM, it is achieved after $24 \mathrm{~h}$. For BNM at this temperature amount of $0.4 \mathrm{~g}$, BNM is sufficient because $0.6 \mathrm{~g}$ of BNM does not increase efficiency.

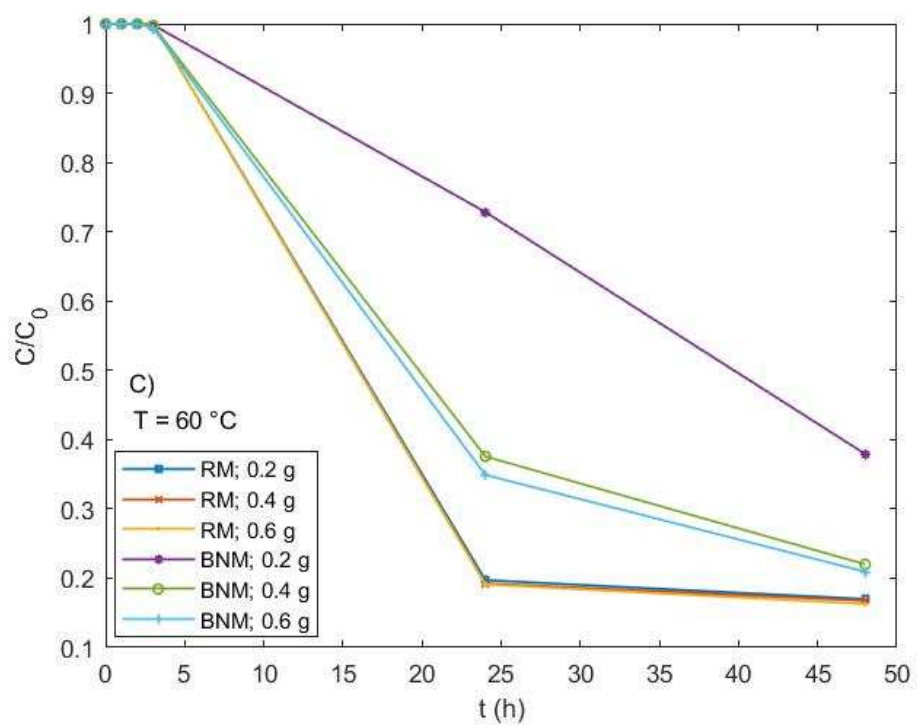

Fig. 7. C) $C / C_{0}$ vs t plot of methylene blue $\left(C_{0}=50 \mathrm{mg} / \mathrm{L}\right)$ adsorption with various dosages of $R M$ and $B N M$ at $60{ }^{\circ} \mathrm{C}$

\section{Conclusions}

Red mud and black nickel mud have been investigated for the removal of methylene blue from the solution. It was found out that red mud exhibits better removal efficiency at increased temperature $\left(40,60^{\circ} \mathrm{C}\right)$ after $48 \mathrm{~h}$ than black nickel mud. Based on the results the best removal efficiency is at $60^{\circ} \mathrm{C}$ for red mud $(83.01-83.72 \%$ after $48 \mathrm{~h}$ ) regardless of the amount of adsorbent added to the solution of methylene blue because the amount of red mud has a negligible effect on adsorption efficiency. The results proved the time and temperature (two of three tested parameters) have a significant impact on sorption efficiency and be economically friendly and influences the simplicity of the operation. Among the study parameters, the weight of the sample has the lowest impact on the overall sorption efficiency. On the other hand, the efficiency of black nickel mud at $60^{\circ} \mathrm{C}$ with the amount of 
0.4 and $0.6 \mathrm{~g}$ is $78 \%$ and $79.07 \%$, needed contact time is $48 \mathrm{~h}$, whereas, for red mud, $24 \mathrm{~h}$ is enough to the similar value of removal efficiency. That means the equilibrium with black nickel mud is achieved after $48 \mathrm{~h}$, but with red mud, it is achieved after $24 \mathrm{~h}$. At this temperature amount of $0.4 \mathrm{~g}$ of black nickel mud is sufficient because $0.6 \mathrm{~g}$ of black nickel mud does not increase efficiency so much. FT-IR analysis showed that some of the peaks decreased or are completely lost after annealing, which may lead to a change in the sorption properties of the adsorbents used. We recommend improving the quality of red mud and black nickel mud and adsorption efficiency by one of many activation methods. However, both of them are effective adsorbents of methylene blue after adjustment and under the right conditions.

\section{References}

Al Bakri Abdullah, M.M., Hussin, K. Bnhussai, K.N., et al. (2012). Fly ash-based geopolymer lightweight concrete using foaming agent. International Journal of Molecular Sciences, 13.

Belviso, C., Kharchenko, A., Agostinelli, E., Cavalcante, F., Peddis, D., Varvaro, G., Yaacoub, N. and Mintova S. (2018). Red mud as aluminium source for the synthesis of magnetic zeolite. Microporous and Mesoporous Materials, 270.

Bhatnagar, A., Vilar, V.J.P., Botelho, C.M.S and Boaventura R.A.R. (2011). A review of the use of red mud as adsorbent for the removal of toxic pollutants from water and wastewater. Environmental Technology, 32(34).

Ciahotný. K., Hlinčík, T. Vagenknechtová, A., Prokeš, O. (2016). Adsorbents for the natural gas drying at CNG stations. Acta Montanistica Slovaca, 21(4).

Cudennec, Y., Lecerf, A. (2006). The transformation of ferrihydrite into goethite or hematite, revisited. Journal of Solid State Chemistry, 179(3).

de Souza, K.C., Antunes, M.L.P., Couperthwaite, S.J. (2013). Adsorption of reactive dye on seawater-neutralised bauxite refinery residue. Journal of Colloid and Interface Science, 396.

Dodoo-Arhin, D., Konadu, D.S., Annan, E., et al. (2013). Fabrication and characterization of Ghanaian bauxite red mud-clay composite bricks for construction applications. American Journal of Materials Science, 3.

Foo, K.Y. (2012). Preparation, characterization and evaluation of adsorptive properties of orange peel based activated carbon via microwave induced $\mathrm{K}_{2} \mathrm{CO}_{3}$ activation. Biosource Technology, 104.

Gotić, M., Musić, S. (2007). Mössbauer, FT-IR and FE SEM investigation of iron oxides precipitated from $\mathrm{FeSO}_{4}$ solutions. Journal of Molecular Structure, 834-836.

Gupta, V.K. and Suhas. (2009). Application of low-cost adsorbents for dye removal - A review. Journal of Environmental Management, 90(8).

Gupta, V.K., Ali, I. and Saini, V.K. (2004). Removal of rhodamine B, fast green, and methylene blue from wastewater using red mud, an aluminum industry waste. Industrial \& Engineering Chemistry Research, 43(7).

Hameed, B.H. (2009). Spent tea leaves: a new non-conventional and low-cost adsorbent for removal of basic dye from aqeous solutions. Journal of Hazardous Materials, 161.

Christou, C., Agapiou, A., Kokkinofta, R. (2018). Use of FTIR spectroscopy and chemometrics for the classification of carobs origin. Journal of Advanced Research, 10.

Kafka, R. and Čambálová, L. (2001). Z dejín výroby hliníka na Slovensku: $k$ 50. výročiu vzniku Závodu Slovenského národného povstania v Žiari nad Hronom. 1st edn. Martin : Neografia, a.s.

Kazak, O., Eker, Y.R., Akin, I., Bingol, H. and Tor, A. (2017). A novel red mud@ sucrose based carbon composite: Preparation, characterization and its adsorption performance toward methylene blue in aqueous solution, Journal of Environmental Chemical Engineering, 5(3).

Klačanská, M., Kobetičová, H., Soldán, M., Haršáni, M. and Kuracina, M. (2017). Calcination of Nickel Mud. Research Papers Faculty of Materials Science and Technology Slovak University of Technology, 25(40).

Kobetičová, H., Sviatskii, V., Gerulová, K., Wachter, I., Nikitin, Y., Blinová, L. and Soldán, M. (2017). The Use of Waste From Bauxite Ore in Sorption of 3,5-Dichlorophenol, From Waste Water. Acta Montanistica Slovaca, 22(4).

Kossaczký E. and Surový J. (1987) Chemické inžinierstvo 2, 5th edn. Bratislava: ALFA.

Kumar, S., Kumar, R. and Bandopadhyay, A. (2006). Innovative methodologies for the utilization of wastes from metallurgical and allied industries. Resources, Conservation and Recycling, 48(4).

Michaeli, E., Boltižiar, M., Solár, V. and Ivanová M. (2012). Skládka priemyselného odpadu lúženca ako príklad environmentálnej zát’aže pri bývalej Niklovej huti Sered'. Životné prostredie, 46(2).

Mockovčiaková, A., Orolínová, Z. Matik, M., Hudec, P., Kmecová, E. (2006). Iron Oxide Contribution to the Modification of Natural Zeolite. Acta Montanistica Slovaca, 11(1)

Namasivayam, C. and Arasi, D. (1997). Removal of Congo Red from wastewater by adsorption onto waste red mud. Chemosphere, 34(2) 
masivayam, C. and Sumithra, S. (2005). Removal of direct red 12B and methylene blue fro water by adsorption onto $\mathrm{Fe}$ (III)/Cr (III) hydroxide, an industrial solid waste. Journal of Environmental Management, 74(3).

Pereira, L. and Alves, M. (2012). Dyes-Environmental Impact and Remediation. Environmental Protection Strategies for Sustainable Development.

Rajasulochana, P. and Preethy, V. (2016). Comparison on efficiency of various techniques in treatment of waste and sewage water - A comprehensive review. Resource-Efficient Technologies 2(4).

Ratnamala, G.M., Shetty, K.V., Srinikethan, G. (2012). Removal of remazol brilliant blue dye from dyecontaminated water by adsorption using red mud: Equilibrium, kinetic, and thermodynamic studies. Water, Air, \& Soil Pollution, 223.

Salleh, M.A.M., Mahmoud, D.K., Karim, W.A.W.A., Idris, A. (2011). Cationic and anionic dye adsorption by agricultural solid wastes: a comprehensive review. Desalination, 280.

Singh, S., Aswath, M.U., Rahul Das Biswas, et al. (2019) Role of iron in the enhanced reactivity of pulverized Red mud: Analysis by Mössbauer spectroscopy and FTIR spectroscopy. Case Studies in Construction Materials, 11.

Sobolewski, A. (1998). Slovak brown coals as a feedstock for the active coke production. Acta Montanistica Slovaca, 3(3).

Soldán, M. and Kobetičová, H. (2015). The Structure of Hazardous Industrial Wastes. International Journal of Current Research, 7(12).

Soldán, M., Čaplovič, L., Galbičková, B. and Gerulová, K. (2013). Evaluation of the Structure of Industrial Wastes. Advanced Materials Research, 664.

Štefušová, K., Václavíková, M., Lovás, M. and Hredzák, S. (2012). Use of magnetic filtration in waste water treatment. Acta Montanistica Slovaca, 17(1).

Thakare, S.R., Thakare, J., Kosankar, P.T. and Mangala, R. P. (2020). A chief, industrial waste, activated red mud for subtraction of methylene blue dye from environment. Materials Today: Proceedings, 29(3).

Tor, A. and Cengeloglu, Y. (2006). Removal of congo red from aqueous solution by adsorption onto acid activated red mud. Journal of Hazardous Materials, 138(2)

Wang, S., Boyjoo, Y., Choueib, A., Zhu, Z.H. (2005). Removal of dyes from aqueous solution using fly ash and red mud. Water Research, 39(1).

Wang, S., Jin, H., Deng, Y. and Xiao, Y. (2020). Comprehensive utilization status of red mud in China: A critical review. Journal of Cleaner Production, 125136.

Yagub, M.T., Sen T.K., Afroze S., et al. (2014). Dye and its removal from aqueous solution by adsorption: A review. Advances in Colloid and Interface Science, 209.

Yin, J., Pei, M., He, Y., Du, Y., Guo W. and Wang, L. (2015). Hydrothermal and activated synthesis of adsorbent montmorillonite supported porous carbon nanospheres for removal of methylene blue from waste water. RSC Advances, 5(109).

Zhong-Pan, H., Ze-Min, G., Xinying, L., Zhong-Yong, Y. (2017) High-surface-area activated red mud for efficient removal of methylene blue from wastewater. Adsorption Science \& Technology, 36(1-2). 